\title{
QIPP: cutting budgets or working smarter?
}

IN BRIEF

- Describes the four components of a new initiative being introduced across the NHS: quality, innovation, prevention and productivity.

- Provides an overview for the general dental practitioner.

- Highlights the potential impact this agenda may have on NHS dentistry.
VERIFIABLE CPD PAPER

\begin{abstract}
The Department of Health's response to the national budget deficit is to ensure that the provision of NHS services is guided by four fundamental 'OIPP' principles: Quality, Innovation, Prevention, and Productivity. This agenda will govern all aspects of the National Health Service's (NHS') health care provision for the foreseeable future. NHS dental services will, like all other NHS services, need to make a contribution to the QIPP agenda. The purpose of this paper is to outline the implications for NHS dentistry.
\end{abstract}

\section{CLINICAL RELEVANCE}

Assurance of the quality of the service provided is a requirement for NHS dental practitioners working to GDS contracts or PDS agreements. This may encompass demonstration of quality; registration with the Care Quality Commission (CQC) and compliance with essential decontamination requirements; and professional revalidation with the General Dental Council (GDC). Prevention, delivered as part of a care pathway, should be consistent and evidence-based, and offers an opportunity to utilise skill mix. From a NHS commissioner's perspective robust contract management and efficient referral systems can increase productivity. From a practitioner's perspective new business models may need to be considered to increase productivity and ensure profitability. Innovation, new thinking and new ways of working are required to deliver all of the above. Clinical engagement between dental commissioners and practitioners is critical to provide a reciprocal understanding of the pressures

\footnotetext{
"NIHR Clinician Scientist \& Honorary Specialist Registrar in Dental Public Health, University of Manchester; ${ }^{2}$ Specialist Registrar and Honorary Lecturer in Dental Public Health, University of Manchester; ${ }^{3}$ Professor of Dental Public Health and Primary Care, School of Dentistry, The University of Manchester

*Correspondence to: Dr Paul R. Brocklehurst, School of Dentistry The University of Manchester, Coupland III, Oxford Street, Manchester, M13 9PL

Email: paul.brocklehurst@postgrad.manchester.ac.uk

Refereed Paper

Accepted 9 December 2010

DOI: 10.1038/sj.bdj.2011.286

${ }^{\oplus}$ British Dental Journal 2011; 210: 369-373
}

faced by both parties and to produce agreed solutions to increase productivity.

\section{INTRODUCTION}

The global economic downturn has deeply affected all sectors of the economy in the United Kingdom. ${ }^{1}$ Spending on the NHS is guaranteed until the end of the 2010/2011 financial year and will rise to £114.4 billion. ${ }^{2}$ Although the coalition government has committed to increases in health spending in real terms in each year of the parliament, ${ }^{3}$ the extent of financial growth is likely to be limited and is anticipated to be outstripped by the ever increasing demands on healthcare, due to the growing and ageing population. This mismatch in funding and demand is estimated to be in the region of £15-20 billion up to 2014 (Fig. 1) unless cost efficiency savings are made.

In response to these issues, the Department of Health has circulated guidance based on four fundamental workstreams:4,5 Quality, Innovation, Productivity, and Prevention (Table 1). 'QIPP' will govern all aspects of NHS service provision for the foreseeable future. ${ }^{3}$ The purpose of this paper is to outline the possible implications for each of these workstreams for NHS dentistry in England from a dental commissioner's perspective.

\section{QUALITY}

For dentists practising in England, there are a number of additional statutory and regulatory requirements relating to quality that require professional implementation in 2011 and beyond (Table 2). ${ }^{6,7}$ These stem from Lord Darzi's NHS Next Stage Review ${ }^{6}$ which identified quality as the key organising principle of the NHS. Darzi defined quality as having three key elements: patient safety, the patient experience and the effectiveness of care. The quality agenda informed the pledges, enshrined in the NHS Constitution ${ }^{8}$ regarding the standard of care that patients should expect, including the environment in which this is delivered.

An important recommendation that arose from Darzi's review is the development of Quality Indicators (QIs), which are a means of measuring quality in both the processes and outcomes of health care provision. QIs can be used to evaluate processes that are put in place to achieve specific outcomes, or to determine whether these outcomes have been met. For example, a 'process' quality indicator could be the proportion of children given appropriate preventive fluoride interventions, ${ }^{9}$ while the 'outcome' quality indicator would be the proportion of children remaining decay-free. Use of both types of QI is essential to understand when outcomes have been met, and if not, the reasons for underachievement. ${ }^{6,7}$

\section{Why are Qls important for GDPs?}

The use of QIs will impact upon the services provided by NHS dental practitioners in the future as the NHS seeks to improve the quality of care that it delivers. ${ }^{4,5}$ QIs enable general dental practitioners (GDPs) 
to provide information to the public regarding the quality of services that they deliver and will assist in the production of Quality Accounts (QAs). Under the last government a framework for QA reporting by dentists was developed and was to be piloted and evaluated during 2010. ${ }^{10}$ The change in government has resulted in a hiatus in progressing this work but QAs will be required to pursue the White Paper on Health's key themes of quality and choice for patients. ${ }^{11}$ The paper details the Government's intention to revise and extend quality accounts to 'reinforce local accountability for performance, encourage peer competition, and provide a clear spur for boards of provider organisations to focus on improving outcomes. ${ }^{11}$ In addition, it seeks to ensure the publication of nationally comparable information for patients and their families to use. ${ }^{11}$

QIs can also be used as key performance indicators (KPIs). The Review of NHS dental services advocated the use of 'blended' contracts to reward performance in terms of both dental activity and the delivery of quality, ${ }^{12}$ something the National Dental Access Programme introduced in the PDS Plus contracts. Indicators of quality can also support practice management, GDPs' personal professional development and clinical audit. Although this appears to represent another layer of bureaucracy for busy GDPs, it is difficult to argue against the need to deliver a quality service and to do this practitioners and commissioners need to be able to assess quality using valid and reliable measures.

\section{PRODUCTIVITY}

Productivity overshadows the other elements of QIPP because of the requirement to make £15-20 billion efficiency savings over the next four years. Productivity describes the relationship between 'inputs' and 'outputs'; getting more output (for example increasing dental access) from the same input (the current dental budget), while efficiency is used to describe how well resources have been used to produce a given level of 'output' (Fig. 2). ${ }^{13}$ Cost savings is a process that aims to reduce the cost of providing the input. In the financial year 2010/11 NHS dental allocations to PCTs were frozen and 2011/12 sees the end of ring-fencing of the NHS dental budget. Under these circumstances, in

\section{Table 1 The QIPP agenda ${ }^{3,4}$}

\begin{tabular}{l|l|l}
\multicolumn{2}{c|}{ Component } & Detail \\
\hline Q & Quality & $\begin{array}{l}\text { Treatment of patients with dignity and respect, in accordance with their human rights } \\
\text { Provision of clinically effective advice and treatments in safe, clean environments }\end{array}$ \\
\hline I & Innovation & Use of new methods of working to deliver positive changes in process and outcomes \\
\hline P & Productivity & $\begin{array}{l}\text { Increased positive health outputs and achievement of value for money within } \\
\text { current and proposed services }\end{array}$ \\
\hline P & Prevention & $\begin{array}{l}\text { Delivery of evidence-based effective advice and treatments to reduce the financial } \\
\text { burden of disease }\end{array}$ \\
\hline
\end{tabular}

\section{Table 2 Statutory and regulatory requirements relating to quality}

\begin{tabular}{|c|c|c|}
\hline Legislation & Detail & Act/Guidance \\
\hline Quality Accounts & $\begin{array}{l}\text { Provide accountability in a similar manner } \\
\text { to financial accounts. Expect to become } \\
\text { mandatory from June } 2012\end{array}$ & $\begin{array}{l}\text { NHS Next Stage Review } \\
2009 \text { Health } \text { Act }^{35} \\
\text { Department of } \\
\text { Health/Monitor }\end{array}$ \\
\hline $\begin{array}{l}\text { Care Quality } \\
\text { Commission }(\mathrm{CQC}) \\
\text { registration }\end{array}$ & $\begin{array}{l}\text { CQC have powers to enforce compliance with } \\
\text { Healthcare Associated Infection Registration (HCAI), } \\
\text { which is required for continued practice. They have } \\
\text { the authority to suspend/de-register services and } \\
\text { close practices that do not meet the requirements. }\end{array}$ & $\begin{array}{l}\text { The Health \& Social } \\
\text { Care Act } 2008^{37} \\
\text { http://www.cqc.org.uk/ }\end{array}$ \\
\hline $\begin{array}{l}\text { Health Technology } \\
\text { Memorandum 01-05 }\end{array}$ & $\begin{array}{l}\text { Compliance with essential } \\
\text { decontamination requirements }\end{array}$ & $\begin{array}{l}\text { Health Technical } \\
\text { Memorandum 01-05: } \\
\text { Decontamination in } \\
\text { Primary Care Dental }{ }^{38}\end{array}$ \\
\hline Equality Act & $\begin{array}{l}\text { Simplifies and supersedes the Disability } \\
\text { Discrimination Act (DDA) from October 2010. The } \\
\text { majority of the provisions came into force on the } \\
\text { 1st of October 2010. The Disability Equality Duty } \\
\text { of the DDA continues to apply to the public sector }\end{array}$ & $\begin{array}{l}\text { Equality Act }{ }^{39} \\
\text { Disability Equality Duty }{ }^{40}\end{array}$ \\
\hline $\begin{array}{l}\text { General Dental } \\
\text { Council revalidation }\end{array}$ & $\begin{array}{l}\text { Compilation of a portfolio of evidence to } \\
\text { support ongoing registration with a focus on: } \\
\text { professionalism } \\
\text { clinical competence } \\
\text { communication } \\
\text { management and leadership }\end{array}$ & $\begin{array}{l}\text { General Dental Council }{ }^{41} \\
\text { http://www.gdc-uk.org/ }\end{array}$ \\
\hline
\end{tabular}

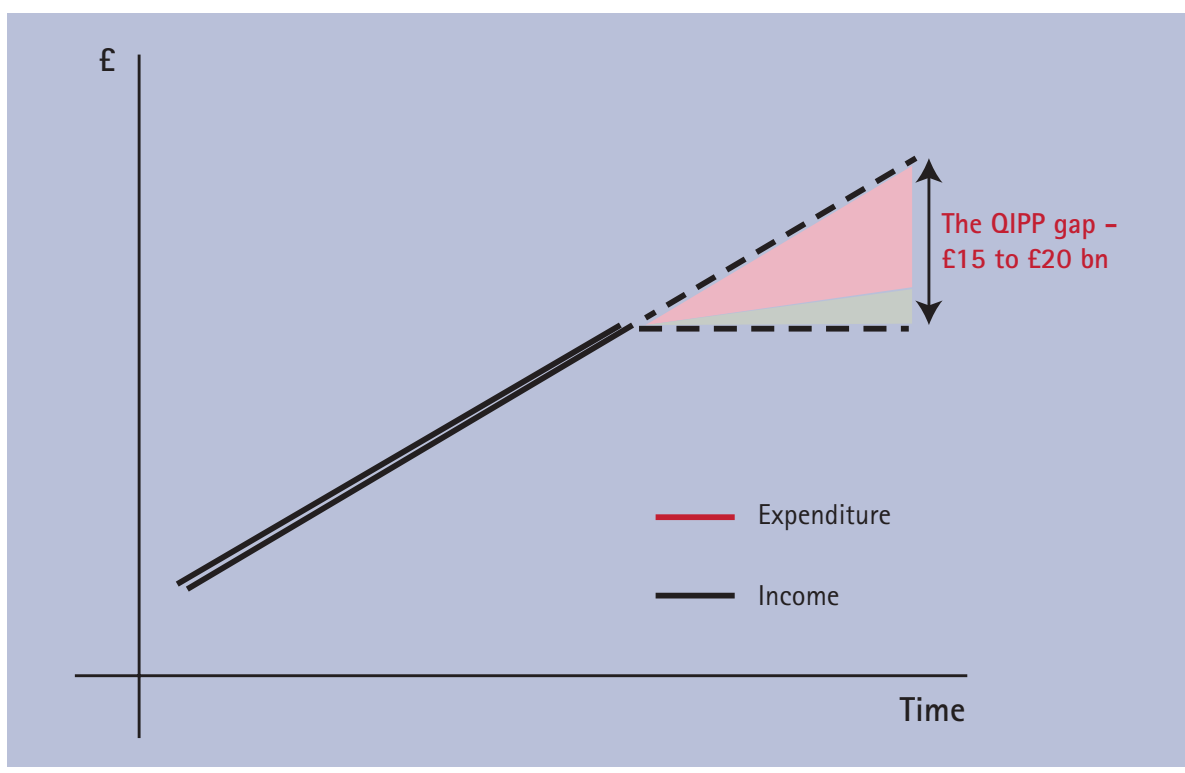

Fig. 1 The QIPP gap produced by the continual growth in expenditure without a matching growth in income

order to increase access to NHS dentistry and address inequalities in utilisation of dental services dental commissioners will need to maximise "value for 
money' and increase the productivity of current contracts.

The historical development of NHS dentistry has required practitioners to generate sufficient profit to offset the cost of their capital assets. ${ }^{14}$ The delivery of care provided by GDPs has been heavily influenced by the need to ensure liquidity and capital growth. In such a market economy, converting demand from consumers into profit naturally becomes the first priority for a successful business. However, from the perspective of the commissioners of dental services, this may mean that patients' 'wants' have been given more priority than the objectively-assessed needs of the local population. ${ }^{15-17}$

This is exacerbated further by the need to achieve Units of Dental Activity (UDA) targets, as there is an incentive in the current contract to provide treatments based upon their UDA value rather than the health gains they provide for patients. This is becoming increasingly apparent as PCTs examine prescribing patterns and contract delivery through the secure online e-reporting software available from NHS Business Services. ${ }^{18}$ For example e-reporting has identified substantial numbers of repeat Band Two and Band Three claims being submitted within a two-month time period for the same patients. ${ }^{18,19}$ A small proportion of these claims will be warranted, however, there is evidence that this trend is at odds with prescribing patterns under the previous GDS contract. Each repeat Band Two and Band Three claim represents an opportunity cost to the PCT of three and 12 UDAs respectively, which could otherwise be utilised eg to purchase clinical time to improve access or deliver prevention. Another area of concern is compliance with NICE guidelines on recall frequency..$^{20}$ E-reporting shows that there has been little change in the frequency of attendance since the NICE guideline was introduced as a mandatory requirement of the dental contract in 2006. Extending recall intervals is problematic for dentists; from a business perspective maintaining a core of regularly attending patients provides financial stability and ever since the NHS began patients have been told to attend every six months, so there is likely to be resistance from patients to extend their recall interval. If the NHS is to expand access and reduce inequalities

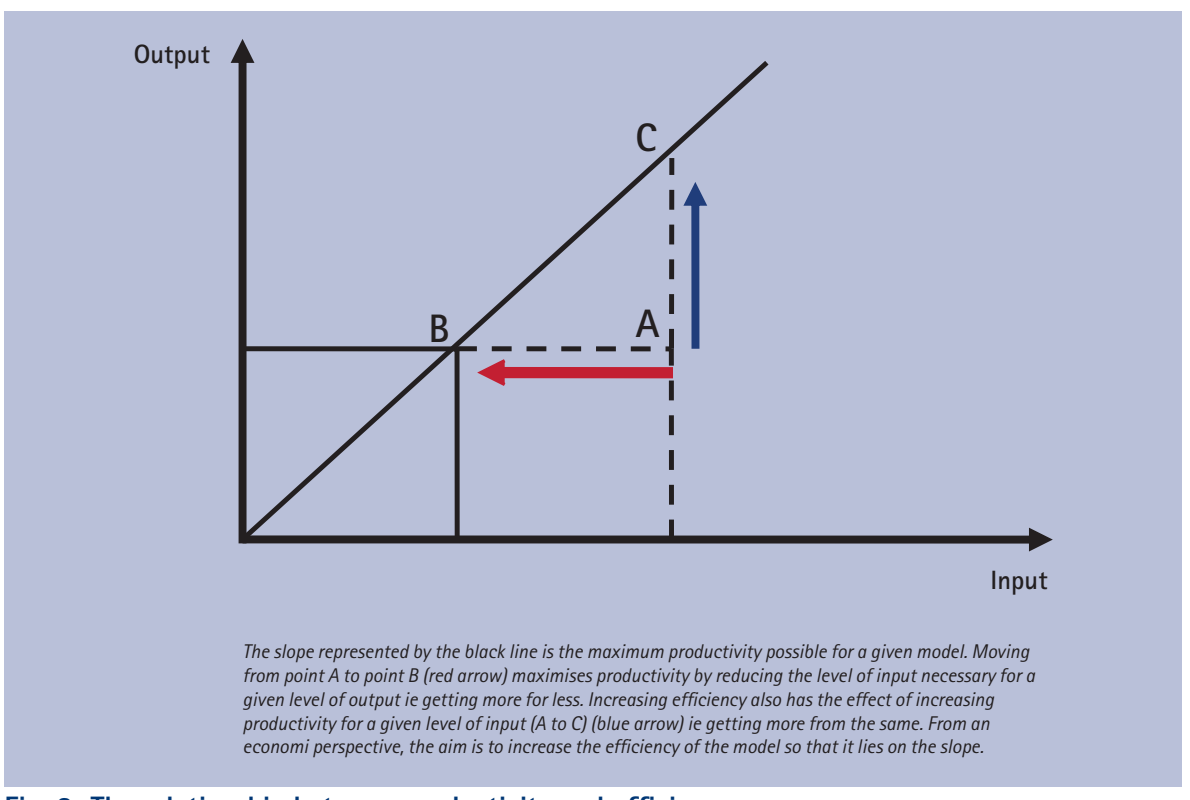

Fig. 2 The relationship between productivity and efficiency

Table 3 Innovative practice to increase efficiency ${ }^{7}$

\begin{tabular}{l|l}
\hline Detail & Enables \\
\hline Increase critical mass & $\begin{array}{l}\text { Expense-sharing } \\
\text { Shared administration } \\
\text { Staff-pooling to reduce disruption to services during periods of sickness/absence } \\
\text { Increased tendering ability }\end{array}$ \\
\hline Clinical engagement & $\begin{array}{l}\text { Reciprocal appreciation of the pressures faced by commissioners and providers } \\
\text { Agreement of contract interpretation to reduce idiosyncrasies in prescribing }\end{array}$ \\
\hline Development of skill mix & $\begin{array}{l}\text { Delegation of simpler treatments to increase clinical capacity and } \\
\text { cost-effectiveness* }\end{array}$ \\
\hline Disease prevention & Evidence-based interventions to reduce disease burden \\
\hline
\end{tabular}

in utilisation of services, under the current budgetary constraints, moving low risk patients to longer recall intervals is crucially important.

QIPP will also focus on referrals into secondary care as these have increased since the introduction of the 2006 contract resulting in significantly increased costs for the NHS. ${ }^{21}$ For example, a simple extraction performed in general practice results in a claim for three UDAs; the same procedure undertaken in secondary care in the North West of England can cost up to $€ 700$. Setting up centralised assessment and triage services and establishing primary care-based specialised services are attractive options to PCTs to manage demand for secondary care services and reduce costs.

The 2006 contract has many grey areas and can be interpreted in different ways. In 2010 the Department of Health produced guidance for both dentists and commissioners on how the contract should be interpreted and managed. ${ }^{22}$ In some areas this guidance has been supplemented at local level by performance management frameworks agreed between the PCT and their contractors. These local agreements can only be achieved through effective clinical engagement and provide clarity for GDPs and commissioners alike on delivering a service based on the 2006 contract.

\section{INNOVATION}

Innovation is the process by which new ideas for improving services are translated into practice and is seen as the means by which increased productivity can be achieved while maintaining or improving quality. Commissioners and practitioners need to jointly consider how to increase productivity and quality of NHS services at the same time as ensuring practices are not destabilised and maintain their 
profitability (Table 3). For example adopting a confederated approach to working should be attractive to smaller businesses, especially single-handed practitioners; coalescence of services increases critical mass and can facilitate expense-sharing arrangements for materials, equipment and staff. Larger, united services also have increased tendering ability so are more likely to secure new contracts and offer greater potential for expansion.

\section{Skill mix}

Another key area of innovation is skill mix. The oral health needs of the population are changing in the United Kingdom, with a broad shift towards better oral health. ${ }^{23,24}$ This is expected to produce a situation where the majority of patients have low treatment needs. ${ }^{25,26}$ Steele argues for a shift from provision of dental activity to oral health improvement ${ }^{12}$ and this will be an important guiding principle in the coalition government's promised new dental contract. ${ }^{27}$ One such model to achieve this aim is the greater use of skill mix. ${ }^{26}$ 'Team working' is an area in which the dental profession has lagged behind its medical counterpart ${ }^{26}$ and can take the form of either supplementation or substitution. ${ }^{28}$ The former describes how nurses provide services which are in addition to services provided by doctors, while the latter is where services previously provided by doctors are undertaken by nurses. In theory, supplementation adds to the overall costs of services, while substitution reduces the costs of services. ${ }^{28}$ The effectiveness and efficiency of skill mix in dentistry under the existing contract and a new contract needs to be investigated further; the roles of dental care professionals are strictly regulated by their Scope of Practice ${ }^{29}$ and so future responsibilities would need to be carefully defined. However, one area in which skill mix could be utilised and potentially provide large increases in productivity is prevention. ${ }^{30}$

\section{PREVENTION}

It can no longer be considered acceptable to simply treat disease which is theoretically preventable, and QIPP recognises the imperative to reduce the burden of disease on services to constrain costs in the long term. Historically, prevention in dentistry has largely been delivered on an ad hoc basis and has often been ineffective. ${ }^{31,32}$ Commissioners are now being encouraged to place a stronger focus on securing preventive services and services to meet local oral health needs. ${ }^{33}$ Delivering Better Oral Health ${ }^{9}$ outlines an evidence-based approach to prevention and PCTs can commission a preventive orientated service now using the Dental Public Health Regulations of the 2006 contract. ${ }^{34}$ The proposed new dental contract is likely to continue this emphasis, with its focus on improving the oral health of school-aged children. ${ }^{27}$ Prevention is critical to QIPP in dentistry as any operative intervention produces irreversible damage, which has lifelong consequences and increases treatment costs to the NHS over the longer term. Commissioners and the tax payer will need to understand that reductions in treatment provision do not necessarily reflect diminished performance in a prevention-orientated service. Use of quality indicators are therefore essential to measure the processes and the outcomes of preventive care.

\section{THE IMPORTANCE OF CLINICAL ENGAGEMENT}

Clinical engagement is critically important if the NHS is to progress the QIPP agenda in dentistry. It describes a consultative process by which service providers actively participate in the strategic change of services. Clinical engagement recognises the co-dependent relationship between the two parties: commissioners rely on providers to deliver services; providers need the support of commissioners to adapt to the significant changes which will affect NHS dentistry over the next three years. When working well it increases trust and helps GDPs to understand the pressures on commissioners and helps commissioners to understand the difficulties faced by GDPs in delivering a service and running a business.

\section{CONCLUSIONS}

The Comprehensive Spending Review reaffirmed the importance of the QIPP programme in making up to $£ 20$ billion of efficiency savings by the end of the spending review period. ${ }^{2}$ This occurs at a time of unprecedented structural change of the NHS, as outlined in the draft White Paper on Health. ${ }^{11}$ These changes will have a significant impact of NHS dental services. On top of all this a new dental contract will be piloted from 2011, based on capitation, registration and the delivery of quality. The team developing the new contract face an extremely complex set of challenges, some of which have been identified above, and it is therefore imperative that the new contract is robustly evaluated. PCTs disappear in April 2013 and dentistry will be commissioned by the NHS Commissioning Board. Local commissioning as we now know it will disappear and dental contracts are likely to be managed more centrally. One of the major concerns raised by these changes is where clinical engagement, which is critical to managing the changes required by QIPP, and implementation of a new contract, will sit in the new world.

The points expressed in this paper are solely those of the authors and do not represent the views of the NHS or NIHR.

1. National Audit Office. Maintaining financial stability across the United Kingdom's banking system. Report by the Controller and Auditor General. London: Stationery Office, 2009.

2. HM Treasury. Comprehensive spending review. Available at: http://cdn.hm-treasury.gov.uk/sr2010_ completereport.pdf. Accessed 27 October 2010.

3. Department of Health. Revision to the Operating Framework for the NHS in England 2010/11. NHS finance: Whitehall, 2010.

4. Department of Health. The NHS quality, innovation, productivity and prevention challenge: an introduction for clinicians. London: Stationery Office, 2010.

5. Department of Health. The quality productivity challenge. http://www.dh.gov.uk/en/ Publicationsandstatistics/Lettersandcirculars/ Dearcolleagueletters/DH_104239 Accessed: 26 March 2010.

6. Professor the Lord Darzi of Denham KBE. High quality care for all. NHS next stage review final report. London: The Stationery Office, 2008.

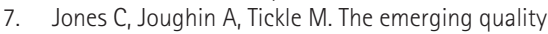
agenda for GDPs in England. Dent Update 2009; 36: 558-568.

8. Department of Health. The NHS Constitution - the NHS belongs to us all. London: HMSO, 2010.

9. Department of Health. Delivering better oral health: an evidence-based toolkit for prevention. 2nd ed. London: HMSO, 2009

10. Department of Health. Quality Accounts toolkit: advisory guidance for providers of NHS services producing Quality Accounts for the year 2009/2010. Available at: http://www.dh.gov. uk/en/Publicationsandstatistics/Publications/ PublicationsPolicyAndGuidance/DH_112359. Accessed 9 April 2010.

11. Department of Health. Equity and excellence: liberating the NHS. 2010. Available at: http://www. dh.gov.uk/en/Publicationsandstatistics/Publications/ PublicationsPolicyAndGuidance/DH_117353

12. Steele J. NHS dental services in England. London: HMSO, 2009.

13. Coelli T J, Prasad Rao DS, O'Donnell C J, Battese $\mathrm{G}$ E. An introduction to efficiency and productivity analysis. 2nd ed. New York: Springer, 2005.

14. House of Commons Health Select Committee. House of Commons Health Committee: Dental Services - Fifth Report of Session 2007-08. 2008

15. Wright J, Williams R, Wilkinson J R. Health needs assessment - development and importance of health needs assessment. BMJ 1998; 316: 1310-1313.

16. Asadi-Lari M, Packham C, Gray D. Need for redefining needs. Health Qual Life Outcomes 2003; $1: 34$.

17. Dixon A, Le Grand J. Is greater patient choice 
consistent with equity? The case of the English NHS. J Health Serv Res Policy 2006; 11: 162-166.

18. Business Services Authority. Available at: http:// www.nhsbsa.nhs.uk/ Accessed: 18 March 2010

19. National Information Centre. Available at: http:// www.ic.nhs.uk/ Accessed: 18 March 2010.

20. National Institute for Health and Clinical Excellence. Dental Recall. Recall interval between routine dental examinations. London: NICE, 2004. Available at: http://www.nice.org.uk/nicemedia/ live/10952/29488/29488.pdf Accessed: 17 May 2010.

21. Department of Health. Payment by results step-bystep guide: calculating the 2010/11 National Tariff. London: Stationery Office, 2010.

22. NHS Primary Care Commissioning. Contract management handbook. Available at: http://www. pcc.nhs.uk/contract-management-handbook. Accessed 5 November 2010

23. Godson J H, Williams S A. Inequalities in health and oral health in the UK. Dent Update 2008; 35: $243-246$

24. Kelly M, Steele J, Nuttall N et al. Adult dental health survey: oral health in the United Kingdom 1998. London: Stationery Office, 2000.

25. Department of Health. Dental workforce resource pack. London: Stationery Office, 2005.

26. Gallagher J E, Wilson N H F. The future dental workforce? Br Dent J 2009; 206: 195-200.

27. HM Government. Freedom, fairness, responsibility. The Coalition: our programme for government.
London: The Stationery Office, 2010.

28. Laurant $M$, Reeves $D$, Hermens $R$, Braspenning J Grol R, Sibbald B. Substitution of doctors by nurses in primary care. Cochrane Database Syst Rev 2005; 18: CD001271

29. General Dental Council. Scope of practice consultation. Available at: www.gdc-uk.org. Accessed: 20 March 2010

30. NHS Primary Care Commissioning. The use of fluoride varnish by dental nurses to control caries. Available at: http://www.pcc.nhs.uk/uploads/ Dentistry/2009/the_use_of_fluoride_varnish.pdf Accessed 5 November 2010.

31. Threlfall A G, Milsom K M, Hunt C M, Tickle M Blinkhorn A. Exploring the content of the advice provided by general dental practitioners to help prevent caries in young children. Br Dent J 2007; 202: 148-149.

32. Kay $E$, Locker $D$. A systematic review of the effectiveness of health promotion aimed at improving oral health. Community Dent Health 1998; 15: 132-144.

33. Department of Health. Improving dental access, quality and oral health. London: HMSO, 2009.

34. Harris R, Bridgman C. Introducing care pathway commissioning to primary dental care: the concept. Br Dent J 2010; 209: 233-239.

35. Department of Health. Health Act 2009. Available at: http://www.legislation.gov.uk/ukpga/2009/21/ contents (accessed 12 April 2011).
36. Keogh B, Bennett D. Quality Accounts for 2010-11, Gateway reference number: 15119. Dear colleague letter. Available at: http://www.dh.gov.uk/prod_ consum_dh/groups/dh_digitalassets/documents/ digitalasset/dh_122541.pdf (accessed 12 April 2011).

37. Department of Health. The Health and Social Care Bill 2008. Available at: http://www.dh.gov.uk/en/ Publicationsandstatistics/Legislation/Actsandbills/ HealthandSocialCareBill/index.htm (accessed 12 April 2011).

38. Department of Health. Health Technical Memorandum 01-05: Decontamination in primary care dental practices. London: Department of Health, 2009. Available at: http://www.dh.gov. uk/prod_consum_dh/groups/dh_digitalassets/ documents/digitalasset/dh_112542.pdf (accessed 12 April 2011)

39. HM Government. Equality Act 2010. Available at: http://www.legislation.gov.uk/ukpga/2010/15/ contents (accessed 13 April 2011).

40. HM Government Directgov website. The Disability Equality Duty webpage. http://www.direct.gov. uk/en/DisabledPeople/RightsAndObligations/ DisabilityRights/DG_10038105 (accessed 13 April 2011).

41. General Dental Council. Revalidation webpage. http://www.gdc-uk.org/Dentalprofessionals/ Revalidation/Pages/default.aspx (accessed 13 April 2011). 